\title{
MATERNAL AND FCETAL LIPIDS OF SHEEP
}

\author{
By D. R. BODY and F. B. SHORLAND \\ Department of Scientific and Industrial Research, Fats Research \\ Laboratory, Wellington, New Zealand
}

$\mathrm{O}^{\mathrm{s}}$ VER the past fow years investigations on the lipids of the total tissues, excluding wool, skin and hoofs, of maternal and fœetal sheep havo been carried out in this Laboratory. As typical of the findings in this project wo report the results obtained for a Romnoy ewo born in spring 1958 and killed on June 8, 1962 (when prognant with two foetuses 8-10 weeks old), and a Romney fotal ram lamb, still-born on August 11, 1961. The tissues of the ewe (excluding fœetuses) and of the fotal lamb were procossed as described by Barton and Kirton ${ }^{1}$ while the lipids were extracted as outlined by Shorland, Bruco and Jessop ${ }^{2}$. The characteristies of the lipids are given in Table 1 .

Table 1. Characteristics of the Total Maternal and fotal Lipids

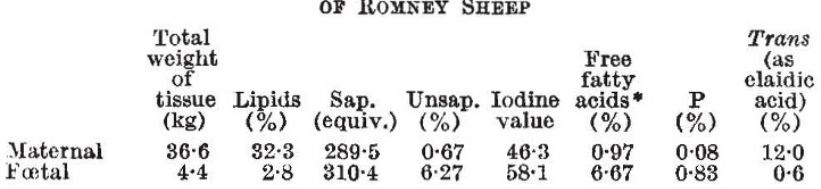

*Calculated as oleic acid.

The relatively low lipid content of the new-born as compared with that of the well-nourishod adult animal shown in Table 1 is in keeping with the obsorvations of othor workers ${ }^{3}$.

Aithough the percentages of phospholipids and of unsaponifiable matter are shown in Table 1 to be approximately ten times greater in the fœtal as compared with the maternal lipids, whon expressed on a fat-free basis the levels of these constituents in tho two tissues aro found to be similar.

Using the rubbor membrane technique of Van Beers, do Iongh and Boldingh ${ }^{4}$ tho lipids wero separated into phospholipid and triglycerido fractions. The fatty-acid composition (Table 2) of these fractions was determinod by gas chromatography using 20 por cent polydiethylene glycol adipate on 'Celite 545' with argon carrier gas at $207^{\circ}$ and a radioactive strontium detector ${ }^{5}$ under tho conditions described by Gerson ${ }^{8}$.

The triglycerides of the maternal lipids are shown to contain (Table 2) substantial amounts of $n$-odd numbered

Table 2. FATTY-Acid COMPOSITION OF MATERNAL AND FCETAI TRIGLYCeRIDes AND PhospLolipids. FATtY ACIDS MOLES PER CENT*

\begin{tabular}{|c|c|c|c|c|c|}
\hline \multirow{2}{*}{\multicolumn{2}{|c|}{ Fatty acids }} & \multicolumn{2}{|c|}{ Maternal } & \multicolumn{2}{|c|}{ F'cetal ${ }^{y}$} \\
\hline & & $\begin{array}{c}\text { Tri- } \\
\text { glycerides }\end{array}$ & $\begin{array}{l}\text { Phospho- } \\
\text { lipids }\end{array}$ & $\begin{array}{c}\text { Tri- } \\
\text { glycerides }\end{array}$ & $\begin{array}{c}\text { - Phospho- } \\
\text { lipids }\end{array}$ \\
\hline Saturated & $\begin{array}{l}\mathrm{C}_{14} \\
\mathrm{C}_{15} \\
\mathrm{C}_{16} \\
\mathrm{C}_{17} \\
\mathrm{C}_{28} \\
\mathrm{C}_{29} \\
\mathrm{C}_{20} \\
\mathrm{C}_{38}\end{array}$ & $\begin{array}{l}1.63 \\
0.76(0.16) \\
24.15(0.32) \\
2.27(0.63) \\
26.29 \\
\text { - } \\
-\end{array}$ & $\begin{array}{l}0.42 \\
0.42(0.09) \\
20.40(0.02) \\
1.26(0.32) \\
25.99 \\
\overline{0.34} \\
-\end{array}$ & $\begin{array}{c}0.62 \\
\overline{25 \cdot 97} \\
13 \cdot 25 \\
= \\
--\end{array}$ & $\begin{array}{c}1.16(0.06) \dagger \\
0.68(0.22) \\
24.28(0.28) \\
0.70(0.11) \\
15.49 \\
0.17 \\
0.35 \\
0.28\end{array}$ \\
\hline Unsatwrated & 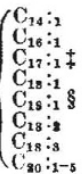 & $\begin{array}{r}0.25 \\
1.84 \\
1.00 \\
37.74 \\
1.03 \\
2.04 \\
1.00 \\
-\end{array}$ & $\begin{array}{r}-1.19 \\
2 \cdot 88 \\
0.88 \\
0.28 \\
0 \cdot 36 \\
7 \cdot 25 \\
2 \cdot 18 \\
3 \cdot 03\end{array}$ & $\begin{array}{r}\overline{1 \cdot 45} \\
\overline{58 \cdot 71} \\
= \\
=\end{array}$ & $\begin{array}{r}0.23 \\
5.88 \\
0.65 \\
46.88 \\
\text { trace } \\
0.42 \\
\overline{2.85}\end{array}$ \\
\hline
\end{tabular}

* Assuming areas under peaks are proportional to molecular concentrations. + Figures in brackets indicate the amount of branched chain acid included. + Figures in brackets indicate the amount

Includes some $\mathbf{C}_{18}$ branched chain acid.
(4.03 per cent) and of branched chain acids ( $1 \cdot 11$ per cent) as well as of linoleic acid (2.04 per cent) and linolenic acid (1.00 por cent). Tho aforementioned acids wore not detected in the fœtal glycerides under the conditions of analysis used. However, the $n$-odd numbered and branched chain acids shown in Table 2 were found in trace amounts (less than 0.1 per cent) by gas chromatographic analysis of appropriate concentrates prepared by oster fractionation. These rosults together with the data for the fœetal phospholipids show that the $n$-odd numbered and branched chain acids do not pass readily from the mother through the placenta.

The occurrence of considorable amounts (12.0 per cent) of trans acids in tho maternal lipids as compared with 0.6 por cent found in the fotal lipids is in agreement with the observations of other workers ${ }^{7}$. In this regard, it may be noted that whereas the maternal triglyceride fatty acids contained 1.03 per cont of trans octadoc-16enoic, this acid was absent from the fotal triglycorides, although presont to the extent 0.36 per cent in the corresponding phospholipid fatty acids. The relatively high stearic acid content of the maternal lipids as compared with that of the foetus is also significant (Table 2).

The passage of unsaturated acids, including oleic and linoleic acids, across the placenta has been indicated for guinea pigs ${ }^{8}$ while othor workers have shown that the dienoic acids from corn oil and the hoxaonoic acids from cod liver oil also pass across the placenta of the rabbit ${ }^{9}$. In the presont work, although di- and poly-enoic acids were not found in the fotal triglycerides thore is evidence that linoleic but not linolonic acid occurs in the foetal phospholipids.

Consistent with the possibility of the $\mathrm{C}_{20}$ unsaturated acids being mainly synthesized within the fœtus, rather than being transported through the placenta, is the occurrence of mainly eicosatrienoic acid in the fuetal phospholipids and of mainly eicosatetraenoic acid and eicosapentaenoic acids in tho ewe phospholipids.

Using column ${ }^{10}$ and papor ${ }^{2}$ chromatographic techniques it was shown that tho phospholipid fractions of the maternal and foetal lipids were similar in composition containing approximately by woight (per cent) phosphatidyl choline, 50; phosphatidyl othanolamine, 25; sphingomyolin, 10; phosphatidyl serine, 7; phosphatidyl inositol, 3, and unidentified, 5. However, as already indicated, the fatty acid composition of the total phospholipid fractions of the maternal and fœetal lipids showed minor differences.

${ }^{1}$ Barton, R. A., and Kirton, A. H., Nature, 178, 920 (1956).

${ }^{2}$ Shorland, F. B., Bruce, I. W., and Jesson, A. S., Biochem. J., 52, 400 (1952). Widdowson, E. M., Nature, 166, 626 (1950).

- Van Beers, G. J., de Iongh, H., and Boldingh, J., Fourth Intern. Conf. Biochem. Problems of Lipids, 43 (Oxford, 1957).

'Lovelock, J. F., James, A. T., and Pipor, F. A., Ann. N.Y. Acad. Sci., 72, $720(1959)$.

- Gerson, T., J. Chromatog, 6, 178 (1961).

7 Johnston, P. V. Johnston, O. C., and Kummerow, F. A., Proc. Soc. Exp. Biol. Med., 9 6, 760 (1957).

- Satomura, K., and Söderhjelm, I., Texas Rep. Biol. Med., 20, 671 (1962).

- Söderhjelm, L., Acta Soc. Med. Upsal., 58, 239 (1953).

${ }^{10}$ Rouser, G., Bauman, A. J., Kritchevsky, G., Heller, D., and O'Brien, J. S., J. Amer. Oil Chem. Soc., 38, 544 (1961).

11 Rouser, G., Bauman, A. J., Nicolaides, N., and Heller, D., J. Amer. Oit Chem. Soc., 38, 565 (1961). 